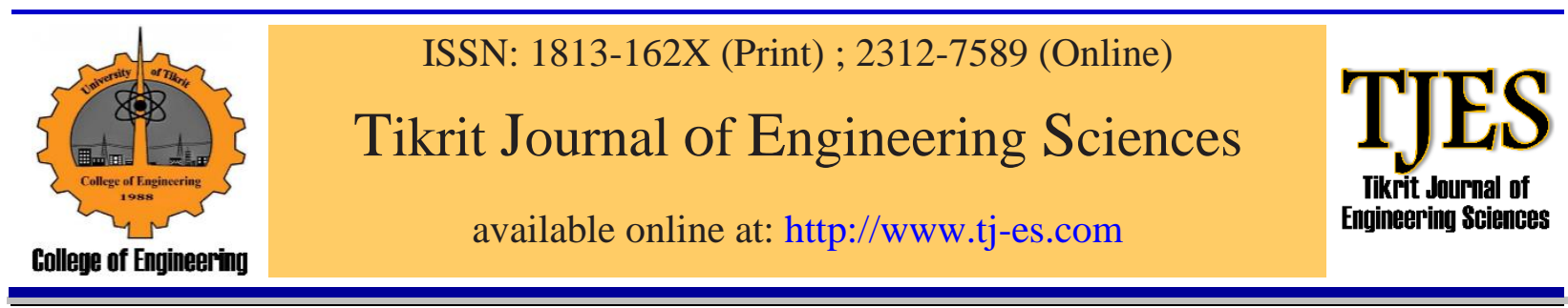

\title{
Investigation of Local Scour around L-Shape Submerged Groynes in Clearwater Conditions
}

\author{
Saleh Issa Khassaf *, Budoor Mohammed Rashak
}

Civil Engineering Department, College of Engineering, University of Basrah, Basrah, Iraq.

Keywords:

Submerged Groyne, Local scour, Clearwater conditions, Contour maps.

\section{A R T I C L E I N F O}

\begin{tabular}{ll}
\hline Article history: & \\
Received & 09 Sep. 2020 \\
Accepted & 20 June. 2021 \\
Available online & 09 Nov. 2021
\end{tabular}

(C2021. COLLEGE OF ENGINEERING, TIKRIT UNIVERSITY. THIS IS AN OPEN ACCESS ARTICLE UNDER THE CC BY LICENSE

http://creativecommons.org/licenses/by/4.0/

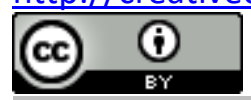

Citation: Shahab MM, Hardan SM, Hammoodi AS . A new Transmission and Reception Algorithms for Improving the Performance of SISO/MIMO- OFDM Wireless Communication System. Tikrit Journal of Engineering Sciences 2021; 28(3): 159- 169.

DOI: http://doi.org/10.25130/tjes.28.3.12

\section{A B S T R A C T}

Submerged Groynes are low profile linear structures that are generally located on the outside bank to form Groynes fields and prevent the erosion of stream banks by redirecting highvelocity flow away from the bank. This research was studied in detail through two major stages. The first stage of the study is based on laboratory experiments to measure the development of local scour around L-shape submerged Groyne with the time, and special attention is given to the effects of different hydraulic and geometric parameters on local scour. Also; maps were drawn showing contour lines that represented the bed levels for maximum scour depth after reaching the equilibrium case. The result showed that a decrease in the scour depth ratio due to the increasing submerged ratio, and the number of Groynes. While the scour hole geometry will increase with the Froude number, flow intensity, and the spacing between Groynes, the decreasing percentage in the scour hole was measured to be about (4.3) \% and (4.4) \% for decreasing the spacing between Groynes from $\left(2 \mathrm{~L}_{\mathrm{g}}\right)$ to $\left(1.5 \mathrm{~L}_{\mathrm{g}}\right)$. Besides, it was range about (11.1) \% and (14.0) \% when reducing the spacing from $\left(1.5 \mathrm{Lg}_{\mathrm{g}}\right)$ to $\left(\mathrm{Lg}_{\mathrm{g}}\right)$ under the same value of maximum Froude number. The second stage of the study is based on experimental results. A new formula was developed by using statistical analysis and it was found that a good determination coefficient.

\footnotetext{
* Corresponding Author: Saleh Issa Khassaf, E-mail: saleh.khassaf@uobasrah.edu.iq, Civil Engineering Department, College of Engineering, University of Basrah, Basrah, Iraq.
} 


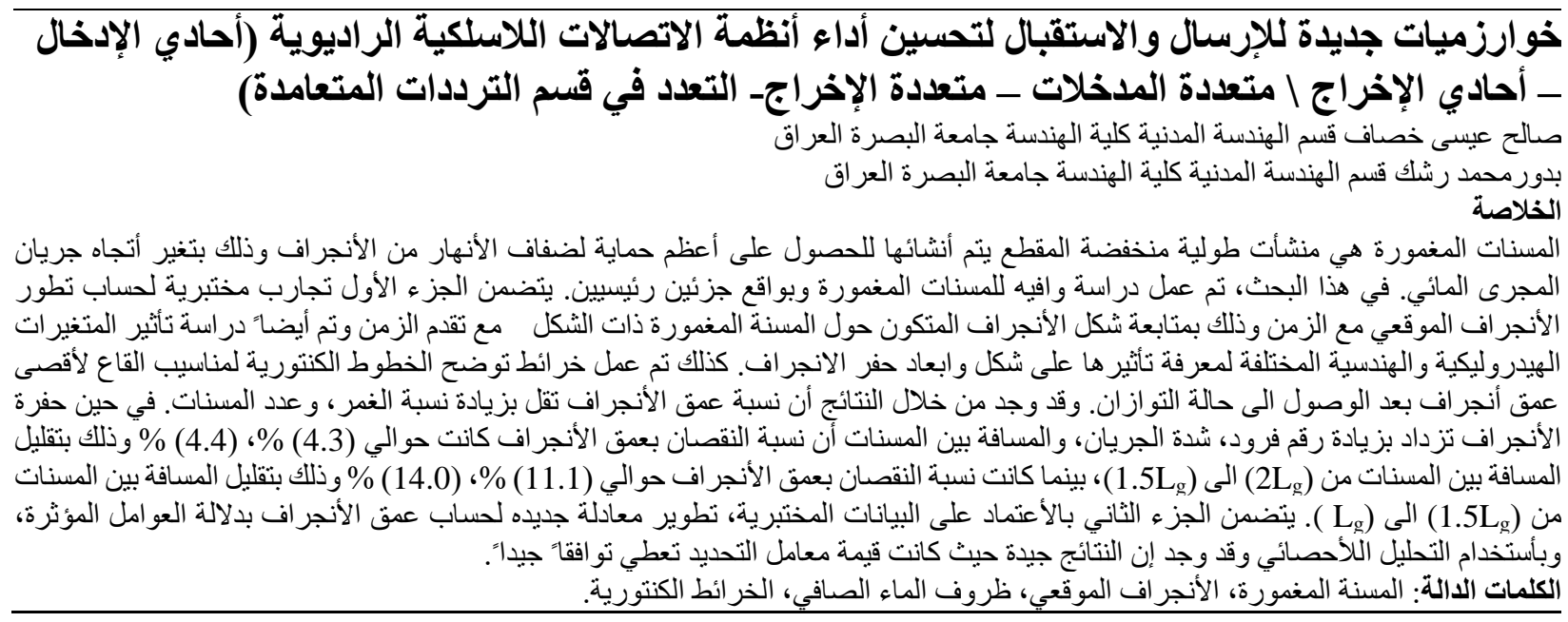

\section{INTRODUCTION}

Scour has been known as a severe risk to the performance of flowing water in any river. The scour phenomenon can be defined as a natural reduction quantity under a supposed designated level (generally the river bed level before incipience of scouring). Furthermore; it can occur under each flow state but the scour impact is higher in the condition of a larger flow. The advantages of scouring and fill in the riverbed during a flood have an important relation to the river bank stability [1]. Goynes are the hydraulic structures that have functions of protecting bank erosion and maintaining water level through deflecting flow direction, a series of Groynes in a row may also be placed on one side or both sides of a river to form a groyne field, commonly utilized in river engineering to avoid bank erosion and control river meandering [2]. The total scours for any stream can be categorized into three major types: general scour and localized scour, where the latest has also divided into sub-divisions of scour, namely contraction and local scour [3]. The general scour is defined as the exclusion of sediments from the river bed by the flowing stream and lowering the river bed that observes as a response for increasing flow discharge [4].

It can further be divided into long-term and shortterm scour that are differentiated by the period development of the scour hole, short -term general scour occurs due to single or several closely spaced floods especially the size and time of concentration [5]. While localized scour: This type; counter to general scour is taken place due to the presence of hydraulic structures. On the other hand, it is divided into contraction scour and local scour [6]. The contraction scour is a lowering of the streambed across the stream or waterway bed at the Groyne. Contraction scours results from constriction of the flow which results in the removal of material from the bed across all or most of the channel width [7]. The local scour is one of the most important concerns in the design and implementation of Groynes. Local scour may occur for two distinct sediment transport conditions, clear water scour refers to local scour that occurs when the velocity of flow is less than the value needed to initiate sediment motion or critical velocity on the bed material upstream of the structure $\left(\mathrm{v} \leq \mathrm{v}_{\mathrm{c}}\right.$, where $v_{c}$ is the critical mean velocity). Hence, the sediments are at rest. live bed scour refers to local scour that occurs when the velocity of flow exceeds the value necessary to initiate sediment motion (suspended and or bed load) upstream $\left(\mathrm{v}>\mathrm{v}_{\mathrm{c}}\right)$, however; the sediments are being transported by the flow [8], As stated by Melville [5], critical mean velocity $\left(v_{c}\right)$ can be obtained from the logarithmic of the velocity profile using equation (a)

$$
v_{c} / v_{*_{c}}=5.75 \log \left(5.53 \frac{y}{d_{50}}\right)
$$

Where $\mathrm{y}=$ depth of flow in $\mathrm{mm}$ and $d_{50}=$ median partial size distribution of bed material in $\mathrm{mm} . \mathrm{v} *_{c}=$ critical shear velocity for the median particle size in $\mathrm{m} / \mathrm{s}$, which can be determined using equation (b), as stated by Melville [5]:

$v_{* c}=0.0115+0.0125\left(d_{50}\right)^{1.4}$

The flow velocity should be smaller than the critical flow velocity, and larger than half of the critical flow velocity, to achieve the clear flow condition [9].

\section{THE EXPERIMENTAL FLUME}

The flume used in this research, as shown in Fig. 1 (a) and (b). It is made of fibreglass reinforced plastic with steel reinforcement, with $(5.64 \mathrm{~m})$ long, $(0.6 \mathrm{~m})$ wide and has a height of ( $0.4 \mathrm{~m})$. The flume included three sections:

The first section consists of an inlet tank located the upstream of the flume with measurements of $\left(0.2 * 1.17^{*} 0.6 \mathrm{~m}\right)$ for long, height and wide respectively, the second section of the flume is the working section consists of the rectangular weir (o.6 $\mathrm{m})$ wide and $(0.35 \mathrm{~m})$ depth utilized to measure the flow discharge. Gravel and screens to distributed the 
flow uniformly over the width of the flume and. While In the middle, the layer of sand of $(0.1 \mathrm{~m})$ thickness, at the end of working section a sediment basin (0.4 $\mathrm{m}^{*} \mathrm{O} .3 \mathrm{~m}$ ) for long and height respectively, the depth of flow is controlled by a tailgate provider with wheels level. The third section of the flume is a reservoir (0.75 $\left.\mathrm{m}^{*} 1.17 \mathrm{~m}^{*} 0.6 \mathrm{~m}\right)$ for the long, height and wide respectively, which supply the water through a recirculating flume of the closed water system through a centrifugal pump. The centrifugal pump attached with an electric motor of maximum capacity equals $(8.4 \mathrm{l} / \mathrm{sec})$. Flow depth was measure by using Point gauge with $( \pm 0.1 \mathrm{~mm})$ accuracy mounted on a carriage which can be moved transversely and longitudinally over the working section by a couple of parallel rails supported on the flume wall.

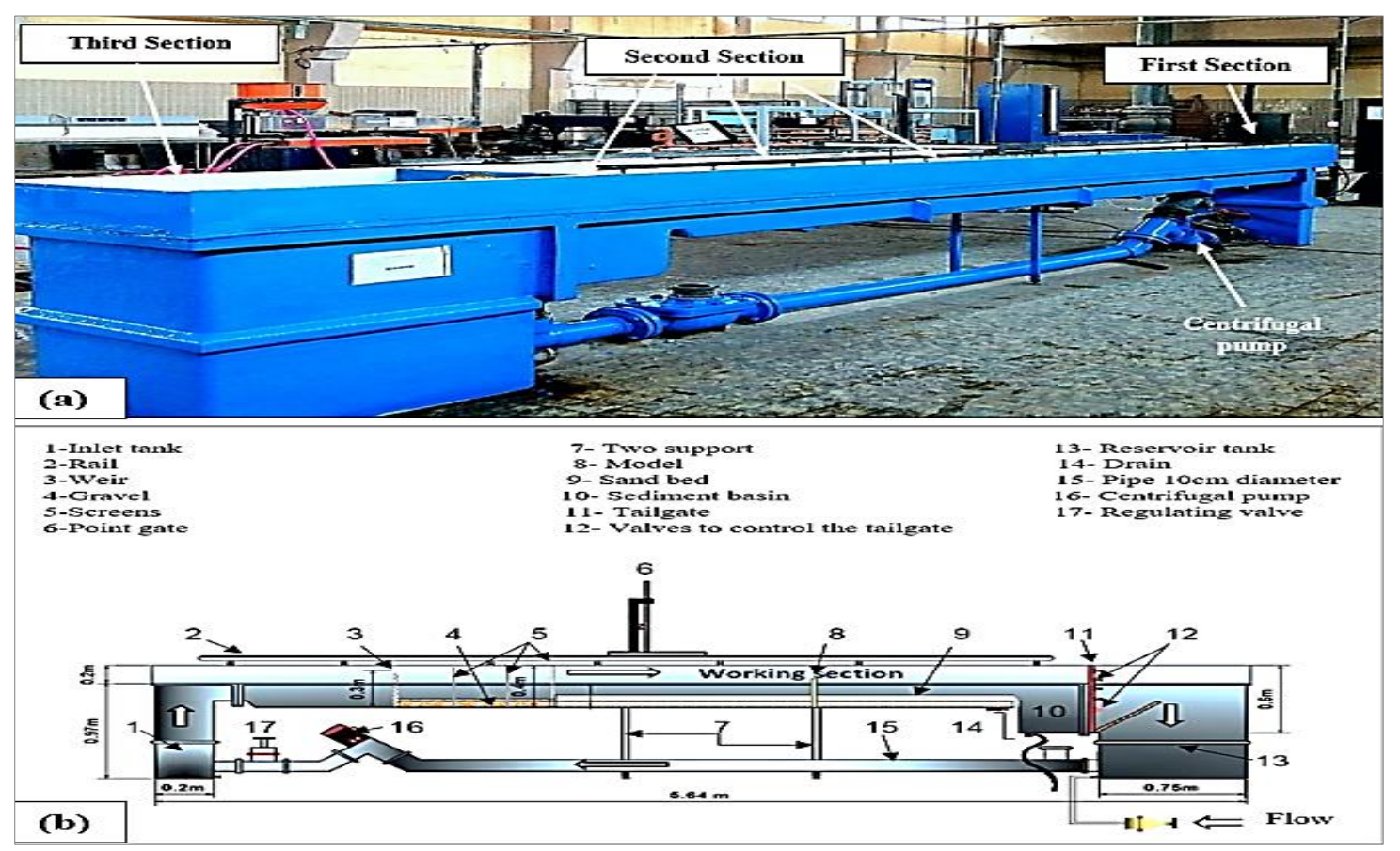

Fig. 1. Detailed drawing of a laboratory flume.

\section{THE EXPERIMENTAL MODELS}

Submerged Groyne L-shape type models were utilized in all the experiments, the models were made of polystyrene foam material of thickness (1) $\mathrm{cm}$ and height $\left(\mathrm{H}_{\mathrm{g}}\right)(15) \mathrm{cm}$ of which (5) $\mathrm{cm}$ is the net height (height of submerged Groyne should have between

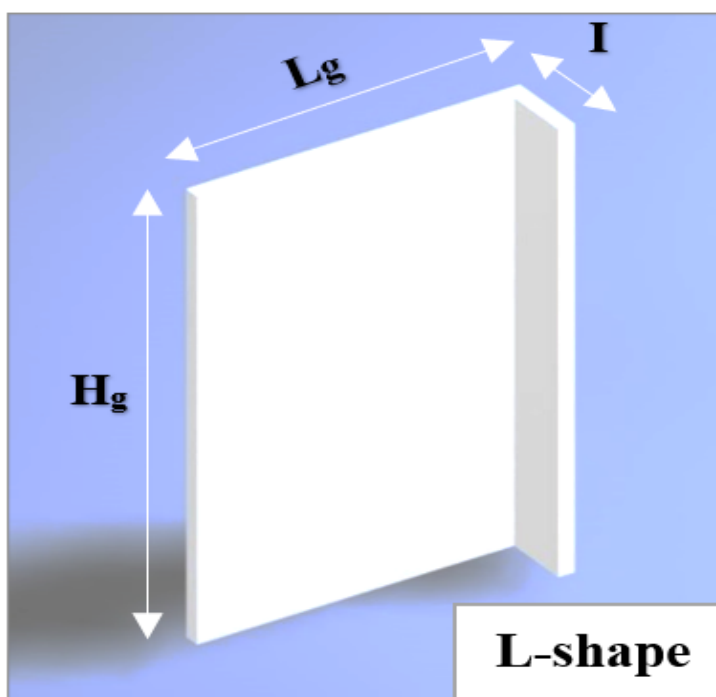

Fig. 2. Sketches for the Groynes models' shapes.
$1 / 3$ and $1 / 2$ of flow depth) [10].

While; (20) cm projection length $\left(\mathrm{L}_{\mathrm{g}}\right)$ (approximately not less than one-third of the flume width [11], and (10) $\mathrm{cm}$ is the projection length of the Groyne which parallel to the flow direction (I) as appeared in Fig. 2 and 3.

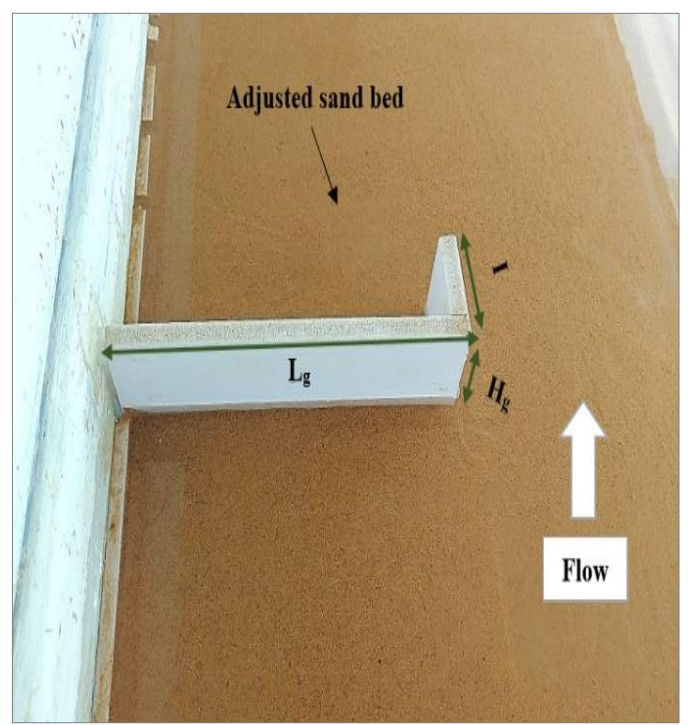

Fig. 3. The L- shape Groynes in the flume. 


\section{THE BED MATERIALS}

Mechanical sieve analysis was carried out to classify the sand bed material. The tests showed that the bed material consists of cohesionless sand with the mean partial size of $\left(d_{50}=0.3\right) \mathrm{mm}, \mathrm{d}_{50}$, is taken as a median particle sediment size and the level of uniformity distribution particle size in this study is characterized by the geometric standard deviation of $\left(\sigma_{\mathrm{g}}=1.32\right) . \sigma_{\mathrm{g}}$ is expressed as $\sigma \mathrm{g}=\sqrt{\frac{d 84}{d 16}}$, it is usually accepted that the sediment may be considered uniform if $\left(\sigma_{g}<1.4\right)$ and no uniform else According to Zhang and Nakagawa [12]. Fig. 4 explains the grain size distribution curve.

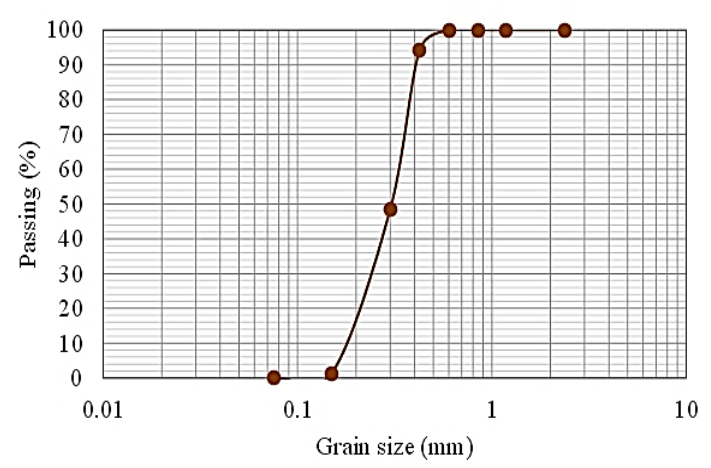

Fig. 4. The distribution curve of grain size for bed material $\left(\mathrm{d}_{50}=0.3\right) \mathrm{mm}$.

\section{TIME OF THE EQUILIBRIUM}

The time needed to find the equilibrium conditions of scouring to be used in all tests is important to know it for avoiding the impact of the time and introduced an equilibrium time at $95 \%$ of the end scour [13]. Several experimental runs were carried out. Five various velocities were utilized and the scour was recorded at a specified time interval spans by using a point gauge to measure the maximum scour depth at the nose of the upstream Groyne. From Fig. 5; the depth of scouring is sharply increased in the first third of the test period, then the development of scour depth with the time has become almost constant. It should be aforementioned that (v) is expressed as the average velocity of flow while $\left(v_{c}\right)$ is express as the average velocity at the primary motion of the bed sediment of flow. Besides, it has been noticed that about (95\%) of the local scour depth accomplished in (2-hours), For more accuracy, the time is lasted as (3-hours) for all test runs.

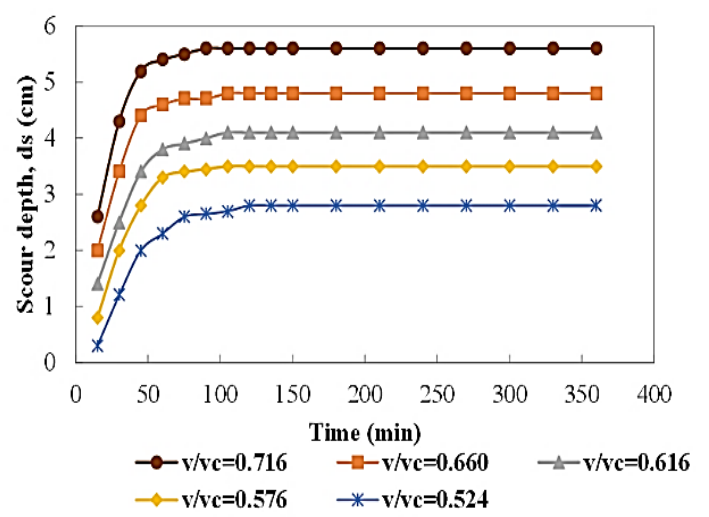

Fig. 5. Development of scour depth with the time using L-shape Groyne.

\section{ANALYSIS AND DISCUSSION}

Discussing and analyzing the results acquired from the laboratory data is a more important step in designing the submerged Groynes. To decrease the effect of scour depth phenomena. All the experimental work was performed in steady subcritical flow and clear water conditions. All the experimental results utilized in the study are listed in Table 1.

Table 1.

Experimental results using L-shape submerged Groyne.

\begin{tabular}{|c|c|c|c|c|c|c|c|c|c|c|c|c|}
\hline $\begin{array}{c}\text { Run } \\
\text { No. }\end{array}$ & $\begin{array}{c}\mathrm{h}_{0} \\
(\mathrm{~cm})\end{array}$ & $\begin{array}{c}\mathrm{h}_{1} \\
(\mathrm{~cm})\end{array}$ & $\begin{array}{c}\mathrm{v} \\
(\mathrm{m} / \mathrm{s})\end{array}$ & $\begin{array}{c}\mathrm{v}_{\mathrm{c}} \\
(\mathrm{m} / \mathrm{s})\end{array}$ & $\begin{array}{c}\mathrm{b} \\
(\mathrm{cm})\end{array}$ & $\mathrm{n}$ & Fr & $\mathrm{v} / \mathrm{v}_{\mathrm{c}}$ & $\mathrm{h}_{1} / \mathrm{h}_{0}$ & $\mathrm{~b} / \mathrm{h}_{0}$ & $\mathrm{ds}$ & $\mathrm{ds} / \mathrm{h}_{0}$ \\
\end{tabular}

The tested intensity of flow and submerged ratio using single L-shape Groyne

\begin{tabular}{|c|c|c|c|c|c|c|c|c|c|c|c|c|}
\hline 1 & 7.5 & 2.5 & 0.179 & 0.250 & 0 & 1 & 0.208 & 0.716 & 0.33 & 0.0 & 5.6 & 0.75 \\
\hline 2 & 7.5 & 2.5 & 0.165 & 0.250 & 0 & 1 & 0.192 & 0.660 & 0.33 & 0.0 & 4.8 & 0.64 \\
\hline 3 & 7.5 & 2.5 & 0.154 & 0.250 & 0 & 1 & 0.180 & 0.616 & 0.33 & 0.0 & 4.1 & 0.55 \\
\hline 4 & 7.5 & 2.5 & 0.144 & 0.250 & 0 & 1 & 0.168 & 0.576 & 0.33 & 0.0 & 3.5 & 0.47 \\
\hline 5 & 7.5 & 2.5 & 0.131 & 0.250 & 0 & 1 & 0.153 & 0.524 & 0.33 & 0.0 & 2.8 & 0.37 \\
\hline 6 & 11 & 6 & 0.179 & 0.263 & 0 & 1 & 0.172 & 0.680 & 0.55 & 0.0 & 2.3 & 0.21 \\
\hline 7 & 10 & 5 & 0.179 & 0.259 & 0 & 1 & 0.180 & 0.691 & 0.50 & 0.0 & 3 & 0.30 \\
\hline 8 & 9 & 4 & 0.179 & 0.256 & 0 & 1 & 0.190 & 0.699 & 0.44 & 0.0 & 4.3 & 0.48 \\
\hline 9 & 8 & 3 & 0.179 & 0.252 & 0 & 1 & 0.202 & 0.710 & 0.38 & 0.0 & 5 & 0.63 \\
\hline 10 & 7 & 2 & 0.179 & 0.247 & 0 & 1 & 0.216 & 0.724 & 0.29 & 0.0 & 6.2 & 0.89 \\
\hline
\end{tabular}


Tested the different spacing between two L-shape Groynes three times $(\mathrm{Lg}, 1.5 \mathrm{Lg}, 2 \mathrm{Lg})$

\begin{tabular}{|c|c|c|c|c|c|c|c|c|c|c|c|c|}
\hline 11 & 7.5 & 2.5 & 0.179 & 0.250 & 40 & 2 & 0.208 & 0.716 & 0.33 & 5.3 & 4.7 & 0.63 \\
\hline 12 & 7.5 & 2.5 & 0.165 & 0.250 & 40 & 2 & 0.192 & 0.660 & 0.33 & 5.3 & 3.9 & 0.52 \\
\hline 13 & 7.5 & 2.5 & 0.154 & 0.250 & 40 & 2 & 0.180 & 0.616 & 0.33 & 5.3 & 3.1 & 0.41 \\
\hline 14 & 7.5 & 2.5 & 0.144 & 0.250 & 40 & 2 & 0.168 & 0.576 & 0.33 & 5.3 & 2.4 & 0.32 \\
\hline 15 & 7.5 & 2.5 & 0.131 & 0.250 & 40 & 2 & 0.153 & 0.524 & 0.33 & 5.3 & 1.8 & 0.24 \\
\hline 16 & 11 & 6 & 0.179 & 0.263 & 40 & 2 & 0.172 & 0.680 & 0.55 & 3.6 & 1.7 & 0.15 \\
\hline 17 & 10 & 5 & 0.179 & 0.259 & 40 & 2 & 0.180 & 0.691 & 0.50 & 4.0 & 2.2 & 0.22 \\
\hline 18 & 9 & 4 & 0.179 & 0.256 & 40 & 2 & 0.190 & 0.699 & 0.44 & 4.4 & 3.3 & 0.37 \\
\hline 19 & 8 & 3 & 0.179 & 0.252 & 40 & 2 & 0.202 & 0.710 & 0.38 & 5.0 & 4.4 & 0.55 \\
\hline 20 & 7 & 2 & 0.179 & 0.247 & 40 & 2 & 0.216 & 0.724 & 0.29 & 5.7 & 5.3 & 0.76 \\
\hline 21 & 7.5 & 2.5 & 0.179 & 0.250 & 30 & 2 & 0.208 & 0.716 & 0.33 & 4.0 & 4.5 & 0.60 \\
\hline 22 & 7.5 & 2.5 & 0.165 & 0.250 & 30 & 2 & 0.192 & 0.660 & 0.33 & 4.0 & 3.6 & 0.48 \\
\hline 23 & 7.5 & 2.5 & 0.154 & 0.250 & 30 & 2 & 0.180 & 0.616 & 0.33 & 4.0 & 2.7 & 0.36 \\
\hline 24 & 7.5 & 2.5 & 0.144 & 0.250 & 30 & 2 & 0.168 & 0.576 & 0.33 & 4.0 & 2 & 0.27 \\
\hline 25 & 7.5 & 2.5 & 0.131 & 0.250 & 30 & 2 & 0.153 & 0.524 & 0.33 & 4.0 & 1.3 & 0.17 \\
\hline 26 & 11 & 6 & 0.179 & 0.263 & 30 & 2 & 0.172 & 0.680 & 0.55 & 2.7 & 1.2 & 0.11 \\
\hline 27 & 10 & 5 & 0.179 & 0.259 & 30 & 7 & 0.180 & 0.691 & 0.50 & 3.0 & 2 & 0.20 \\
\hline 28 & 9 & 4 & 79 & 0.256 & 30 & 2 & 90 & 0.699 & 0.44 & 3.3 & 3 & 0.33 \\
\hline 29 & 8 & 3 & 0.179 & 0.252 & 30 & 2 & 0.202 & 0.710 & 0.38 & 3.8 & 4.1 & 0.51 \\
\hline 30 & 7 & 2 & 79 & 0.247 & 30 & 2 & 0.216 & 0.724 & 0.29 & 4.3 & 4.9 & 0.70 \\
\hline 31 & 7.5 & 2.5 & 0.179 & 0.250 & 20 & 2 & 0.208 & 0.716 & 0.33 & 2.7 & 4 & 0.53 \\
\hline 32 & 7.5 & 2.5 & 0.165 & 0.250 & 20 & 2 & 0.192 & 0.660 & 0.33 & 2.7 & 3.1 & 0.41 \\
\hline 33 & 7.5 & 2.5 & 0.154 & 0.250 & 20 & 2 & 0.180 & 0.616 & 0.33 & 2.7 & 2.3 & 0.31 \\
\hline 34 & 7.5 & 2.5 & 0.144 & 0.250 & 20 & 2 & 0.168 & 0.576 & 0.33 & 2.7 & 1.7 & 0.23 \\
\hline 35 & 7.5 & 2.5 & 0.131 & 0.250 & 20 & 2 & 0.153 & 0.524 & 0.33 & 2.7 & 1 & 0.13 \\
\hline 36 & 11 & 6 & 0.179 & 0.263 & 20 & 2 & 0.172 & 0.680 & 0.55 & 1.8 & 0.9 & 0.08 \\
\hline 37 & 10 & 5 & 0.179 & 0.259 & 20 & 2 & 0.180 & 0.691 & 0.50 & 2.0 & 1.6 & 0.16 \\
\hline 38 & 9 & 4 & 0.179 & 0.256 & 20 & 2 & 0.190 & 0.699 & 0.44 & 2.2 & 2.8 & 0.31 \\
\hline 39 & 8 & 3 & 0.179 & 0.252 & 20 & 2 & 0.202 & 0.710 & 0.38 & 2.5 & 3.6 & 0.45 \\
\hline 40 & 7 & 2 & 0.179 & 0.247 & 20 & 2 & 0.216 & 0.724 & 0.29 & 2.9 & 4.5 & 0.64 \\
\hline
\end{tabular}

Tested the different spacing between three L-shape Groynes three times $(\mathrm{Lg}, 1.5 \mathrm{Lg}, 2 \mathrm{Lg})$

\begin{tabular}{|c|c|c|c|c|c|c|c|c|c|c|c|c|}
\hline 41 & 7.5 & 2.5 & 0.179 & 0.250 & 40 & 3 & 0.208 & 0.716 & 0.33 & 5.3 & 5.7 & 0.76 \\
\hline 42 & 7.5 & 2.5 & 0.165 & 0.250 & 40 & 3 & 0.192 & 0.660 & 0.33 & 5.3 & 4.5 & 0.60 \\
\hline 43 & 7.5 & 2.5 & 0.154 & 0.250 & 40 & 3 & 0.180 & 0.619 & 0.33 & 5.3 & 4 & 0.53 \\
\hline 44 & 7.5 & 2.5 & 0.144 & 0.250 & 40 & 3 & 0.168 & 0.578 & 0.33 & 5.3 & 3.3 & 0.44 \\
\hline 45 & 7.5 & 2.5 & 0.131 & 0.250 & 40 & 3 & 0.153 & 0.526 & 0.33 & 5.3 & 2.5 & 0.33 \\
\hline 46 & 11 & 6 & 0.179 & 0.263 & 40 & 3 & 0.172 & 0.680 & 0.55 & 3.6 & 2.7 & 0.25 \\
\hline 47 & 10 & 5 & 0.179 & 0.259 & 40 & 3 & 0.180 & 0.689 & 0.50 & 4.0 & 3.8 & 0.38 \\
\hline 48 & 9 & 4 & 0.179 & 0.256 & 40 & 3 & 0.190 & 0.699 & 0.44 & 4.4 & 4.4 & 0.49 \\
\hline 49 & 8 & 3 & 0.179 & 0.252 & 40 & 3 & 0.202 & 0.710 & 0.38 & 5.0 & 5.5 & 0.69 \\
\hline 50 & 7 & 2 & 0.179 & 0.247 & 40 & 3 & 0.216 & 0.723 & 0.29 & 5.7 & 6 & 0.86 \\
\hline 51 & 7.5 & 2.5 & 0.179 & 0.250 & 30 & 3 & 0.208 & 0.716 & 0.33 & 4.0 & 5.2 & 0.69 \\
\hline 52 & 7.5 & 2.5 & 0.165 & 0.250 & 30 & 3 & 0.192 & 0.660 & 0.33 & 4.0 & 4.3 & 0.57 \\
\hline 53 & 7.5 & 2.5 & 0.154 & 0.250 & 30 & 3 & 0.180 & 0.619 & 0.33 & 4.0 & 3.8 & 0.51 \\
\hline 54 & 7.5 & 2.5 & 0.144 & 0.250 & 30 & 3 & 0.168 & 0.578 & 0.33 & 4.0 & 3 & 0.40 \\
\hline 55 & 7.5 & 2.5 & 0.131 & 0.250 & 30 & 3 & 0.153 & 0.526 & 0.33 & 4.0 & 2.2 & 0.29 \\
\hline
\end{tabular}




\begin{tabular}{|c|c|c|c|c|c|c|c|c|c|c|c|c|}
\hline 56 & 11 & 6 & 0.179 & 0.263 & 30 & 3 & 0.172 & 0.680 & 0.55 & 2.7 & 2.3 & 0.21 \\
\hline 57 & 10 & 5 & 0.179 & 0.259 & 30 & 3 & 0.180 & 0.689 & 0.50 & 3.0 & 3.4 & 0.34 \\
\hline 58 & 9 & 4 & 0.179 & 0.256 & 30 & 3 & 0.190 & 0.699 & 0.44 & 3.3 & 4.1 & 0.46 \\
\hline 59 & 8 & 3 & 0.179 & 0.252 & 30 & 3 & 0.202 & 0.710 & 0.38 & 3.8 & 5 & 0.63 \\
\hline 60 & 7 & 2 & 0.179 & 0.247 & 30 & 3 & 0.216 & 0.723 & 0.29 & 4.3 & 5.4 & 0.77 \\
\hline 61 & 7.5 & 2.5 & 0.179 & 0.250 & 20 & 3 & 0.208 & 0.716 & 0.33 & 2.7 & 4.5 & 0.60 \\
\hline 62 & 7.5 & 2.5 & 0.165 & 0.250 & 20 & 3 & 0.192 & 0.660 & 0.33 & 2.7 & 3.6 & 0.48 \\
\hline 63 & 7.5 & 2.5 & 0.154 & 0.250 & 20 & 3 & 0.180 & 0.619 & 0.33 & 2.7 & 3.3 & 0.44 \\
\hline 64 & 7.5 & 2.5 & 0.144 & 0.250 & 20 & 3 & 0.168 & 0.578 & 0.33 & 2.7 & 2.1 & 0.28 \\
\hline 65 & 7.5 & 2.5 & 0.131 & 0.250 & 20 & 3 & 0.153 & 0.526 & 0.33 & 2.7 & 1.7 & 0.23 \\
\hline 66 & 11 & 6 & 0.179 & 0.263 & 20 & 3 & 0.172 & 0.680 & 0.55 & 1.8 & 2 & 0.18 \\
\hline 67 & 10 & 5 & 0.179 & 0.259 & 20 & 3 & 0.180 & 0.689 & 0.50 & 2.0 & 2.9 & 0.29 \\
\hline 68 & 9 & 4 & 0.179 & 0.256 & 20 & 3 & 0.190 & 0.699 & 0.44 & 2.2 & 3.5 & 0.39 \\
\hline 69 & 8 & 3 & 0.179 & 0.252 & 20 & 3 & 0.202 & 0.710 & 0.38 & 2.5 & 4.3 & 0.54 \\
\hline 70 & 7 & 2 & 0.179 & 0.247 & 20 & 3 & 0.216 & 0.723 & 0.29 & 2.9 & 5.1 & 0.73 \\
\hline
\end{tabular}

\subsection{Effect of Flow Intensity $\left(v / v_{c}\right)$ on the Local Scour $\left(d s / h_{o}\right)$}

The intensity of flow considers significant parameter that effect on the scour phenomena. To clarify this case, sets of experiments were carried out to establish the relationship between the scour depth ratio $\left(\mathrm{ds} / \mathrm{h}_{\mathrm{o}}\right)$, and the intensity of flow $\left(\mathrm{v} / \mathrm{v}_{\mathrm{c}}\right)$ for the different number of the submerged Groyne. The obtained results are shown in Fig. 6, It can be observed from the figure above; that depth of scouring ratio increased linearly with flow intensity increasing for velocities below the threshold value.

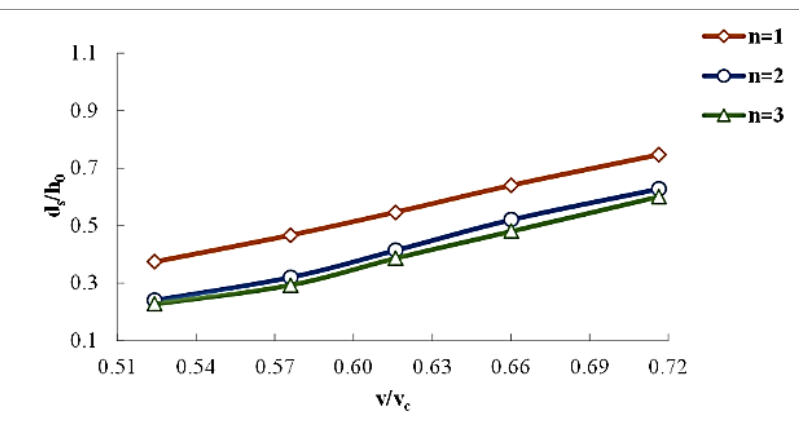

Fig. 6. Effect of flow intensity $\left(v / v_{c}\right)$ on scour depth ratio $\left(\mathrm{ds} / \mathrm{h}_{\mathrm{o}}\right)$ with different number of submerged Groynes.

This may be attributed to the increase in separation region located on the downstream side of the submerged Groyne so more vortices will be formed that in turn cause more scouring.

\subsection{Effect of Submerged Ratio $\left(h_{1} / h_{o}\right)$ on the Local Scour $\left(d s / h_{o}\right)$}

To study the influence of submerged ratio $\left(h_{1} / h_{0}\right)$ on the maximum scour depth ratios $\left(\mathrm{ds} / \mathrm{h}_{\mathrm{o}}\right)$ for the different number of the submerged Groyne. A set of experiments were curried for the purpose to reduce the effect of scouring phenomena, all the experiment results are shown in Fig. 7.

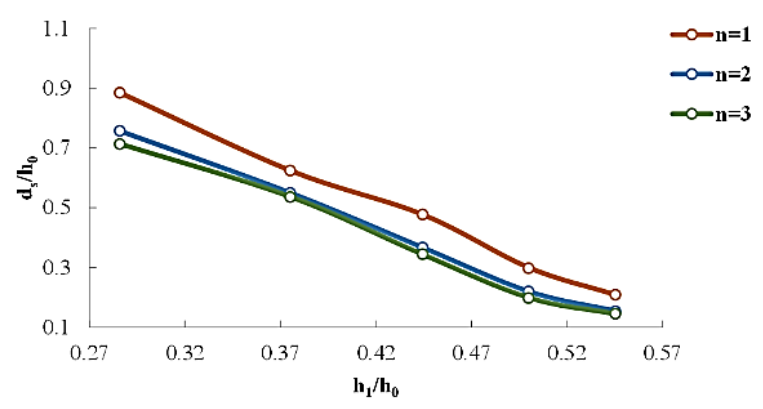

Fig. 7. Effect of submerged ratio $\left(h_{1} / h_{0}\right)$ on scour depth ratio $\left(\mathrm{ds} / \mathrm{h}_{\mathrm{o}}\right)$ with different number of submerged Groynes.

From Fig. 8, it is shown that the overtopping flow does make a significant difference in the value of a scour hole, in which increasing the submerged ratio, is inversely proportional to the scour hole ratio.

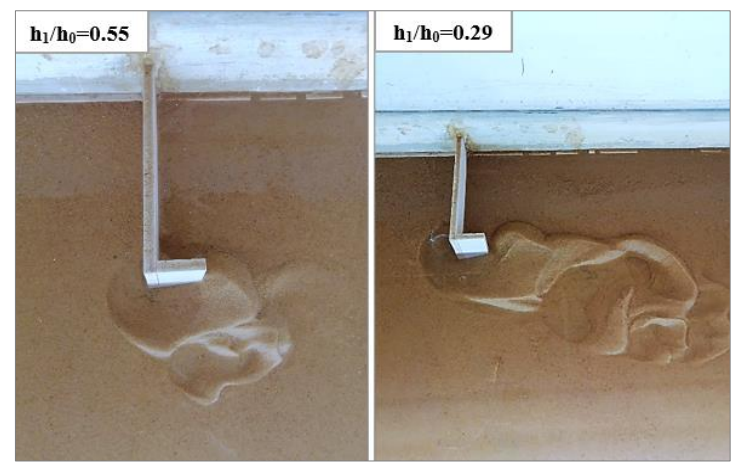

Fig. 8. Photos that clarify the effect of the submerged ratio of flow $\left(h_{1} / h_{0}\right)$ on the ratio of scour depth development $\left(\mathrm{ds} / \mathrm{h}_{\mathrm{o}}\right)$ for single L-shape Groyne.

It is evident that due to the re-circulatory motions practically absent near the free surface at high 
submergence levels, and it will decrease the ability of horseshoe vortices to pick up and entrain sediments.

\subsection{Effect of Froude Number (Fr) on the Local Scour $\left(\mathrm{ds} / \mathrm{h}_{\text {o }}\right)$}

Froude number considers the most important parameters effected on the scour process around the submerged Groyne. Different experiments were conducted to reduce the impact of Froude number (Fr) on the ratio of scour depth $\left(\mathrm{ds} / \mathrm{h}_{\mathrm{o}}\right)$ for a different number of the submerged Groyne and $(b=40 \mathrm{~cm})$, and the obtained results for these experiments has been shown in Fig. 9.

It has been noticed from the figure that the scour depth increases with increasing Froude number based on the law of Froude number that is evident from it that the scour depth increase with increasing the velocity of flow and decreasing in scour depth will increase Froude number value leading to increase the scour depth geometry at a constant flow depth.

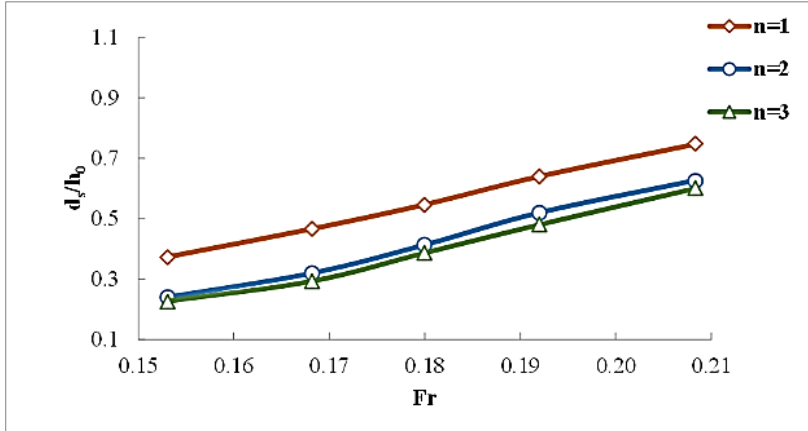

Fig. 9. Effect of Froude number (Fr) on scour depth ratio $\left(d_{s} / h_{0}\right)$ for different number of submerged Groynes.

Fig. 10 presents the effect of increasing Froude number from (0.121 to 0.208), It can be seen that scour phenomena carry out in a wider and larger area, also; when $(\mathrm{Fr}=0.34)$ the fewer sediments were distributed around the scour hole with small camber, while, when $(\mathrm{Fr}=0.49)$; the sediments will collect around the scour depth sides with very high camber, then the sediments starts to decrease and gradually disappear at the far downstream of the Groyne.
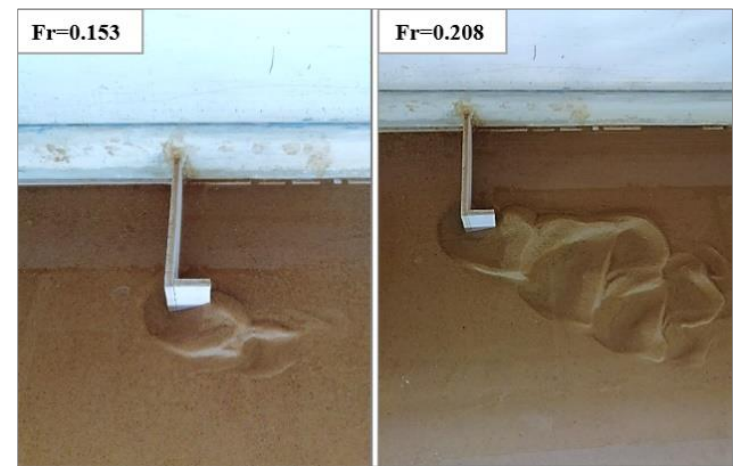

Fig. 10. Photos that clarify the effect of Froude number (Fr) on the ratio of scour depth development $\left(\mathrm{ds} / \mathrm{h}_{\mathrm{o}}\right)$ for single $\mathrm{L}$-shape Groyne.

\subsection{Effect of a Number of the Groyne (n) on the Local Scour $\left(d s / h_{o}\right)$}

Scientific experiments have been conducted to determine the relationship between the scour depth ratio $\left(\mathrm{ds} / \mathrm{h}_{\mathrm{o}}\right)$ and a number of the submerged Groyne (n) for different Froude number, all results of these experiments are shown in Fig. 11. It was observed from the figure; the depth of scour was reduced highly for the first Groyne at the nose of the upstream side. And also observed that the scour region has deeper with much wider space for one Groyne than that of two Groynes and three Groynes.

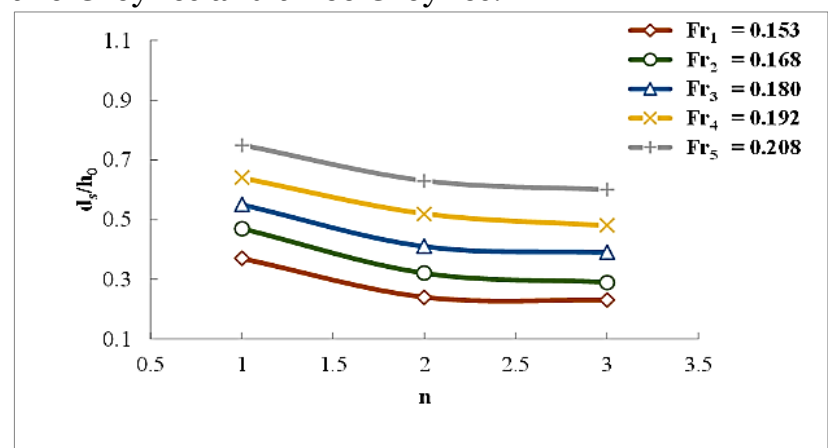

Fig. 11. influence the number of the Groynes (n) on scour depth ratio $\left(\mathrm{ds} / \mathrm{h}_{\mathrm{o}}\right)$ for different Froude number.

This result is illustrated clearly in Fig. 12. The scour is upstream of its nose which higher level of deposition in downstream, while the deposition area starts in a long-distance toward the downstream for one Groyne, for similar experimental flow conditions of maximum Froude number. The decreasing percentage in scour depth when increasing the number of Groynes from one to two was range about (16.1) \%, (19.6) \%, and (28.6) \% for spacing between groynes $\left(2 \mathrm{Lg}, 1.5 \mathrm{Lg}\right.$, and $\left.\mathrm{Lg}_{\mathrm{g}}\right)$ respectively. While it was range about (4.3) \%, (4.4) \%, and (7.5) \% when increasing Groynes number from two to three with the same three spacing between Groynes.

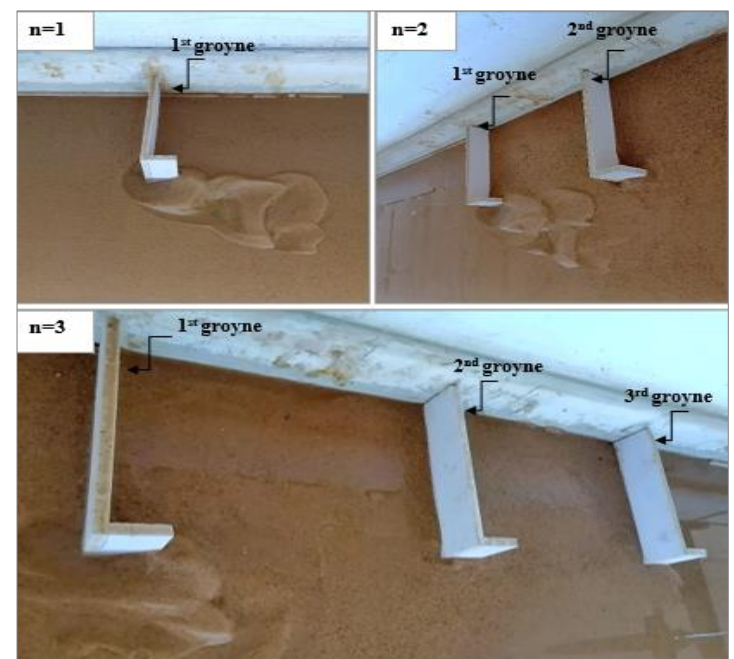

Fig. 12. Photos that clarify the effect of Groynes configuration (n) on the ratio of scour depth development $\left(\mathrm{ds} / \mathrm{h}_{\mathrm{o}}\right)$. 


\subsection{Effect of Spacing between Groynes $\left(b / h_{o}\right)$ on the Local Scour $\left(d s / h_{o}\right)$}

The scouring process has been directly influenced by the spacing between submerged Groynes. Six of the experiments were done for evaluating the relationship between spacing and the scour geometry. The results have been plotted to relate the spacing between the Groynes $\left(\mathrm{b} / \mathrm{h}_{\mathrm{o}}\right)$ with scouring depth ratio $\left(\mathrm{ds} / \mathrm{h}_{\mathrm{o}}\right)$ which is a dimensionless fraction as shown in Fig.13.

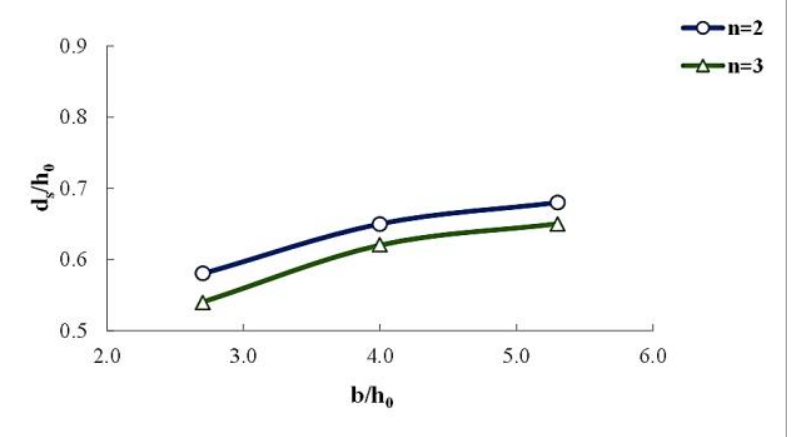

Fig. 13. Impact of spacings between Groynes $\left(b / h_{0}\right)$ on development of scour depth ratio $\left(\mathrm{ds} / \mathrm{h}_{\mathrm{o}}\right)$ for $(\mathrm{L}-$ shape) type.

It can be shown from the figure above that the scouring depth development is higher when increasing the Groynes spacing and lower when reducing the spacing between them, due to the interference between horseshoe vortex. The decreasing percentage in the scour hole was measured to be about (4.3) \% and (4.4) \% for decreasing the spacing between Groynes from $\left(2 \mathrm{~L}_{\mathrm{g}}\right)$ to $\left(1.5 \mathrm{Lg}_{\mathrm{g}}\right.$. Besides, it was range about (11.1) \% and
(14.0) \% when reducing the spacing from $\left(1.5 \mathrm{~L}_{\mathrm{g}}\right.$ ) to $\left(\mathrm{L}_{\mathrm{g}}\right)$ under the same value of maximum Froude number.

\section{BED TOPOGRAPHY PATTERN}

After the end of chosen experiments of maximum Froude number (which most important parameter that effects on local scour), the results of the experiments with maximum Froude numbers are compared with scouring patterns for L-shaped submerged Groynes. The data for bed sand topography levels were contoured using the computer software (Surfer 17). Fig. 14 to 17 illustrate the topography of scour holes and downstream sand bars. Each experiment has similar flow conditions, and submerged Groyne geometry $\left(\mathrm{v} / \mathrm{v}_{\mathrm{c}}=0.716, \mathrm{Fr}=0.208\right.$, and $h_{1} / h_{0}=0.33$ ). It was shown from these figures that the maximum scour depth ratio occurred at the nose of the submerged Groyne. The height of the sand ripples behind the Groyne was observed to be about $(2.5-3.5) \mathrm{cm}$, also scour hole width and volume for single L-shape submerged Groyne is larger than for those of second and third L-shape submerged Groyne; respectively, while all models formed sand bars in the downstream, and also it was observed from the figures that when the spacing is the same as the length of the submerged Groyne $\left(b=L_{g}=20 \mathrm{~cm}\right)$; the sediments deposition starts to concentrate between the Groynes and seems nearer to the following Groyne. while when the spacing between the Groynes increased to twice the length of the Groyne $\left(b=2 L_{g}\right)$ indicating the distance between them has little effect on the scour.

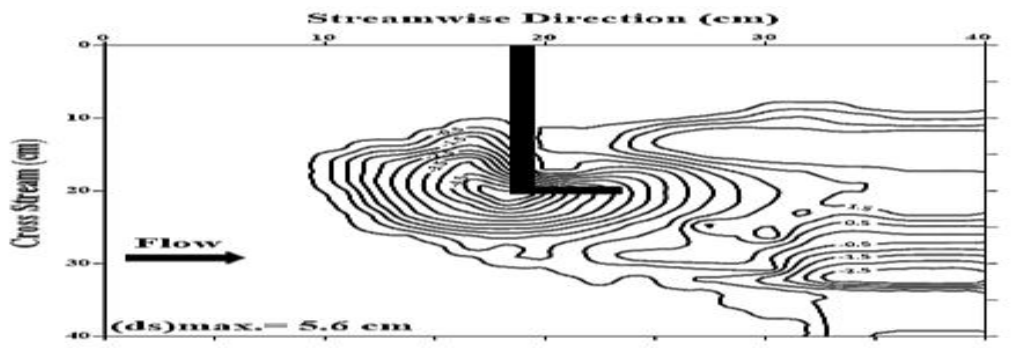

Fig. 14. Contour maps for scouring hole geometry for single L-shape of the submerged Groyne.

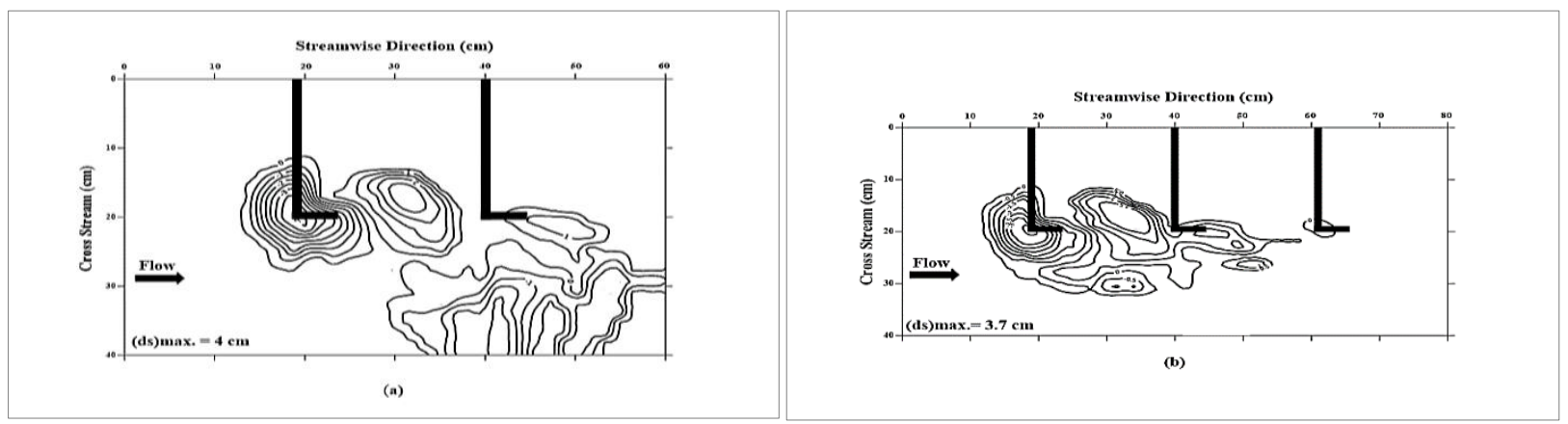

Fig. 15. Contour maps of scour holes submerged Groyne for the cases: (a) Two L-shape Groyne with spacing between them $b=20 \mathrm{~cm}$. (b) Three L-shape Groyne with spacing between them $b=20 \mathrm{~cm}$. 

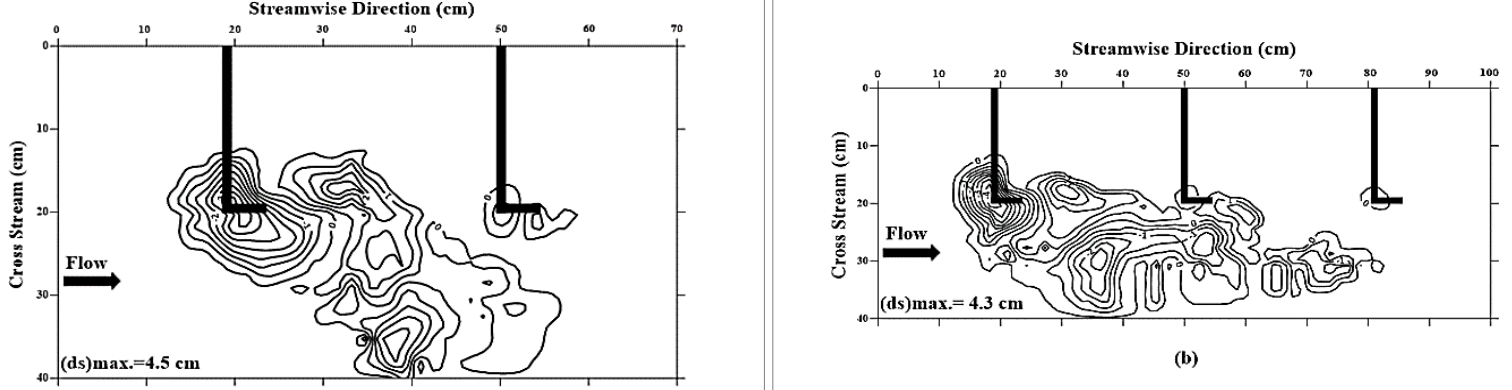

(b)

Fig. 16. Contour maps of scour holes submerged Groyne for the cases: (a) Two L-shape Groyne with spacing between them $b=30 \mathrm{~cm}$. (b) Three L-shape Groyne with spacing between them $b=30 \mathrm{~cm}$.

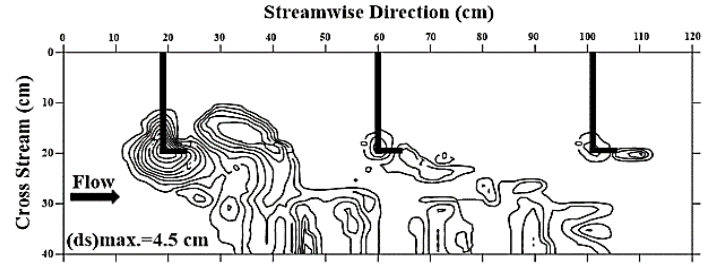

(b)

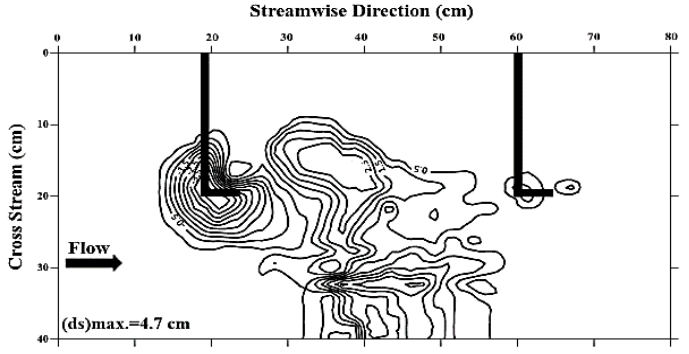

Fig. 17. Contour maps of scour holes submerged Groyne for the cases: (a) Two L-shape Groyne with spacing between them $b=40 \mathrm{~cm}$. (b) Three L-shape Groyne with spacing between them $b=40 \mathrm{~cm}$.

\section{DIMENSIONAL ANALYSIS AND DEVELOPMENT OF THE NEW FORMULA}

Dimensional analysis is a mathematical technique used in study works for design and performing models' experiments. By using this method; the maximum scours depth ratio $\left(\mathrm{ds}_{\max }\right)$ at L-shape submerged Groyne under clear water conditions, the factional relationship may be written as:

$d_{\text {Smax }} f\left\{h_{0}, h_{1}, H_{\mathrm{g}}, v, v_{c}, L_{\mathrm{g}}, \rho, \rho_{s}, \mathrm{~g}, n, b, d_{50}\right.$, $\left.\mu, \sigma_{\mathrm{g}}, B, S_{\circ}, I, \theta\right\}$

The factors definitions are listed in Table 2. By applying the Buckingham's p theorem; after the simplification of the above relationship by dispensing with the terms with constant values and arrangements; Eq. (1) can be written as:

$$
\frac{d_{\text {Smax }}}{h 0}=f_{5}\left(\frac{v}{v_{c}}, \frac{h_{1}}{h_{0}}, F r, n, \frac{b}{h_{0}}\right)
$$

To develop Eq. (2) used to calculate the relative scour depth ratio $\left(\mathrm{ds} / \mathrm{h}_{\mathrm{o}}\right)$ based on the parameters of the non-dimensional formula, which describes an expression for maximum scour depth at the submerged Groyne. The (IBM SPSS Statistics 25) was used to make analysis the formula for L-shape of submerged Groynes through non-linear regression analysis. The obtained expression involves different flow, and geometrical properties, which have an important effect on the local scour criteria. the developed equation is:

$\mathrm{ds} / \mathrm{h}_{\mathrm{o}}=\mathrm{c}_{\mathrm{o}} \times \mathrm{e}^{\left(\mathrm{c}_{1} \times \mathrm{Fr}\right)}+\mathrm{c}_{1} \times \mathrm{e}^{\left(\mathrm{c}_{2} \times \frac{\mathrm{v}}{\mathrm{v}_{\mathrm{c}}}\right)}+\mathrm{c}_{2} \times \mathrm{e}^{\left(\mathrm{c}_{3} \times \frac{\mathrm{h}_{1}}{\mathrm{~h}_{\mathrm{o}}}\right)}+\mathrm{c}_{3} \times \mathrm{e}^{\left(\mathrm{c}_{4} \times \mathrm{n}\right)}$

Where: $c_{0}=-0.395, c_{1}=0.203, c_{2}=2.384, c_{3}=-1.422, c_{4}=0.048$ So the equation becomes:

$\mathrm{ds} / \mathrm{h}_{\mathrm{O}}=-0.395 \times \mathrm{e}^{(0.203 \times \mathrm{Fr})}+0.203 \times \mathrm{e}^{\left(2.384 \times \frac{\mathrm{v}}{\mathrm{v}_{\mathrm{c}}}\right)}+$
$2.384 \times \mathrm{e}^{\left(-1.422 \times \frac{\mathrm{h}_{1}}{\mathrm{~h}_{\mathrm{O}}}\right)}-1.422 \times \mathrm{e}^{(0.048 \times \mathrm{n})}$

To this equation; the coefficient of determination $\left(\mathrm{R}^{2}\right)$ is (0.926). The above equations were derived utilizing (80) \% of the experimental results, then the accuracy of these equations was tested by using other data (around (20) \% of the residual data), these data are substituted in the Eq. (4) and their results were compared with the experimental results to show the predicted convergence to observed records between the predicted $\left(\mathrm{ds} / \mathrm{h}_{0}\right)$ from the formulas) to the observed $\left(\mathrm{ds} / \mathrm{h}_{\mathrm{o}}\right)$ (from the experiments). The value of the coefficient of determination $\left(\mathrm{R}^{2}=0.9008\right)$ is reflected in good agreement for all data as shown in Fig. 18. 


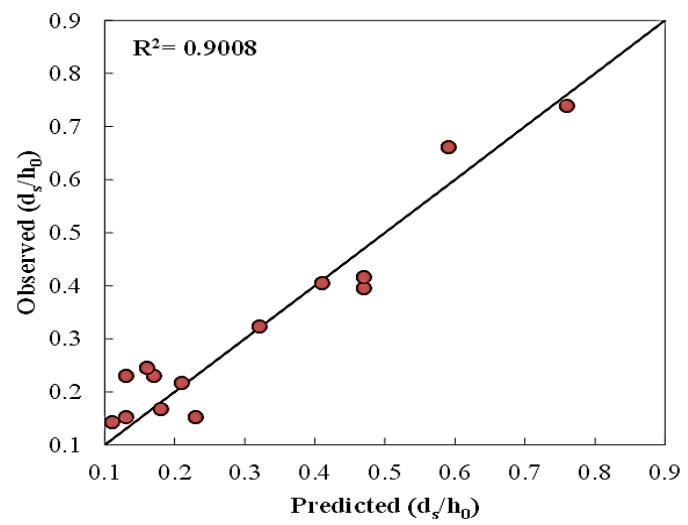

Fig. 18. Validation of Eq. (4) for L-shapesubmerged Groyne with experimental data.
Table 2. The parameters definitions using in statistics

\begin{tabular}{|c|c|c|}
\hline symbol & Definition & Dimension \\
\hline B & Flume width & $\mathbf{L}$ \\
\hline $\mathbf{I}$ & $\begin{array}{l}\text { Projection length of groyne parallel to the flow } \\
\text { direction }\end{array}$ & $\mathbf{L}$ \\
\hline $\mathrm{L}_{\mathrm{s}}$ & Projection length of groyne & $\mathbf{L}$ \\
\hline $\mathbf{H}_{\mathrm{g}}$ & Height of groyne & $\mathbf{L}$ \\
\hline$d_{16}$ & Sediment size for which $16 \%$ of the particle are finer & $\mathbf{L}$ \\
\hline d50 & Median particle grain size & $\mathbf{L}$ \\
\hline$d_{54}$ & Sediment size for which $84 \%$ of the particle are finer & $\mathbf{L}$ \\
\hline ds & local scour depth around the groynes & $\mathbf{L}$ \\
\hline Fr & Froude number & - \\
\hline $\mathrm{g}$ & Gravitational acceleration & $\mathrm{LT}^{-3}$ \\
\hline $\mathbf{n}$ & Number of groynes & - \\
\hline $\mathrm{b}$ & Spacing between the groynes & $\mathbf{L}$ \\
\hline So & The slope of the channel bed & - \\
\hline $\mathbf{h}_{0}$ & F1ow water depth & $\mathbf{L}$ \\
\hline $\mathbf{h}_{1}$ & $\begin{array}{l}\text { Distance from the water surface to the top of the } \\
\text { groyne }\end{array}$ & $\mathbf{L}$ \\
\hline$\theta$ & The angle of groyne inclination & - \\
\hline $\mathbf{v}$ & Mean velocity & $\mathrm{LT}^{-1}$ \\
\hline $\mathrm{v}_{\mathbf{c}}$ & Critical velocity & $\mathrm{LT}^{-1}$ \\
\hline$\sigma_{g}$ & Geometric standard deviation & - \\
\hline$\mu$ & Dynamic viscosity of the fluid & $\mathrm{MT}^{-1} \mathrm{~L}^{-1}$ \\
\hline$\rho$ & Density of fluid & $\mathrm{MT}^{-3}$ \\
\hline$\rho_{s}$ & The density of the sediment & $\mathrm{MT}^{-3}$ \\
\hline
\end{tabular}

used to evaluate the maximum depth of scour under similar conditions.

\section{References}

[1] Abdalla MG. Study on Scour for Irrigation Canals in Egypt, Case Study: The First Reach of ElIbrahimeya Cana. American Journal of Engineering and Technology Management 2017; Mansoura University, Mansoura, Egypt, 1(4): 6577 .

[2] Mostafa MM, Ahmed HSH, Abd-Elraheem GA, Ali NA, Tominaga A. Experimental Study on Flow Characteristics around Single Groyne With Different Permeability in Compound Channel Flood plai, In Proceedings of 2013 IAHR Congress 2013; Tsinghua University Press, Beijin, China.

[3] Lu JY, Hong JH, Su CC, Wang CY, Lai JS. Field Measurements and Simulation of Bridge Scour Depth Variations During Flood. Journal of Hydraulic Engineering ASCE 2008; 134(6): 810821.

[4] Khassaf SI, Obied NA. Experimental Study: Bridge Pier Protection Against Local Scour Using Guide Panel, IOP Conference Series: Materials Science and Engineering 2018; 433(1).

[5] Melville BW, Coleman SE. Bridge Scour. Water Resources Publications 2000; LLC, Colorado, USA,: 550 .

[6] Srivastava S. Pier Scouring Under Live-Bed Conditions. International Journal of Science Technology \& Engineering 2016; 2(11).

[7] Arneson LA, Zevenbergen LW, Lagasse PF, Clopper PE. Evaluating Scour at Bridge. Journal of Hydraulic Engineering, United States 2012; Federal Highway Administration, 18. 
[8] Fathi A, Zomorodian SMA. Effect of Submerged Vanes on Scour Around a Bridge Abutmen. KSCE Journal of Civil Engineering 2018; Korean Society of Civil Engineers, 22(7): 2281-2289.

[9] Hong YM, Chang ML, Lin HC, Kan YC, Lin CC. Experimental Study on Clear Water Scour around Bridge Pier. In Applied Mechanics and Materials, Trans Tech Publications Ltd 2012; 121: 162-166.

[10] Ji1a HJS, Karmacharya B. Flood Control Measures Best Practices Report an Approach for Community-Based Flood Control Measures in the Terai River. first edition, German Technical Cooperation 2000; Kathmandu, Nepal.
[11] Möws R, Koll K. Roughness Effect of Submerged Groyne Fields with Varying Length, Groyne Distance, and Groyne Type. Journal of Water 2019; 11(6).

[12] Zhang H, Nakagawa H. Scour around Spur Dyke. journal of advanced and future researches 2008; no.51b, 633-652.

[13] Melville BW, Chiew YM. Time Scale for Local Scour at Bridge Piers. Journal of Hydraulic Engineering 1999; 125(1): 59-65. 